\title{
Assisted Labor
}

National Cancer Institute

\section{Source}

National Cancer Institute. Assisted Labor. NCI Thesaurus. Code C92738.

An intervention during the childbirth process to help the laboring mother deliver her baby. 